\title{
On the origin of 'iron-cross' twins of pyrite from Mt. Katarina, Slovenia
}

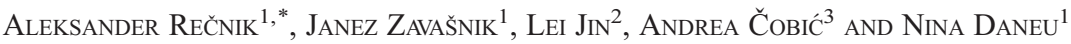 \\ 1 Department for Nanostructured Materials, Jožef Stefan Institute, Jamova cesta 39, SI-1000 Ljubljana, Slovenia \\ 2 Peter Grünberg Institute and Ernst Ruska-Centre (ER-C) for Microscopy and Spectroscopy with Electrons, Research \\ Centre Jülich, D-52425 Jülich, Germany \\ 3 Department of Geology, Faculty of Science, University of Zagreb, Horvatovac 95, CR-10000 Zagreb, Croatia
}

[Received 15 October 2015; Accepted 22 December 2015; Associate Editor: Martin Lee]

\section{ABSTRACT}

Iron-cross twins of pyrite are well known among mineralogists, however it is quite surprising that the conditions of their formation remain unexplored. To address this question we studied pyrite twins from the Upper Permian silts of Mt. Katarina near Ljubljana (Slovenia), which represent one of the most typical geological environments for twinned pyrite. Mineralization of pyrite starts with a reduction of the primary red-coloured hematite-rich sediment by sulfide-rich fluids that penetrated the strata. A short period of magnetite crystallization is observed prior to pyrite crystallization, which indicates a gradual reduction process. Sulfur isotope analysis of pyrite shows an enrichment in $\delta^{34} \mathrm{~S}$, suggesting its origin from the neighbouring red-bed deposit. Other sulfides, such as chalcopyrite and galena, formed at the end of pyrite crystallization. Remnants of mineralizing fluids trapped at the interfaces between the inclusions and host pyrite show trace amounts of $\mathrm{Pb}$ and $\mathrm{Cu}$, indicating their presence in the solutions throughout the period of pyrite crystallization. An electron microscopy and spectroscopy study of twin boundaries showed that interpenetration twinning is accomplished through a complex 3D intergrowth of primary $\{110\} \mathrm{Cu}$-rich twin boundaries, and secondary $\{100\}$ boundaries that are pure. We show that approximately one monolayer of $\mathrm{Cu}$ atoms is necessary to stabilize the $\{110\}$ twin structure. When the source of $\mathrm{Cu}$ is interrupted, the two crystal domains continue to form $\{100\}$ interfaces, that are more favourable for pure pyrite.

KEYwords: red-beds, hematite, magnetite, pyrite, $\mathrm{FeS}_{2}$, iron-cross twins, stacking faults, twin boundaries, transmission electron microscopy, crystal growth.

\section{Introduction}

Pyrite $\left(\mathrm{FeS}_{2}\right)$ is the most widespread sulfide mineral. It is found commonly in hydrothermal sulfide ore deposits, igneous, metamorphic and sedimentary rocks. Regardless of its abundance, twinned crystals are extremely rare and their origin has yet to be determined. 'Iron-cross' twins of pyrite were first described from classic localities of Weserbergland in Germany (Hessel, 1869). Crystallographically, pyrite twins are composed of two interpenetrating crystals rotated by $180^{\circ}$ around

*E-mail: aleksander.recnik@ijs.si

DOI: 10.1180/minmag.2016.080.073 the [110]-axis with respect to each other (Goldschmidt and Nicol, 1904). While crystallographically, the twin law is well known, the true cause of twinning has not yet been identified. On the basis of the mirror symmetry, Gliszczynski (1950) inferred that they might be a result of replacement after some yet unknown mineral. Strunz and Tennyson (1965) suggested that twin symmetry operation is best reproduced, if the local structure of (110) twins of pyrite comprises one atomic layer of marcasite, whereas (101) twins of marcasite would be produced through the local pyrite structure. This was followed by a transmission electron microscopy (TEM) study of pyrite twins by Donnay et al. (1977), who suggested three 
different interface models, and pointed out the problem twin-boundary chemistry.

Based on the available literature on the few known deposits of twinned pyrite, some general observations can be made on their geological environment. Twinned crystals of pyrite occur predominantly in sedimentary deposits (e.g. Vlotho-Exter, Germany; Obidos, Portugal; Gilman, Colourado; etc.) and less commonly in skarn-type hydrothermal ore deposits (e.g. Dognecea, Romania and Rio Marina, Elba), where iron oxides (mainly hematite) preceded the crystallization of iron sulfides. In sedimentary environments the 'iron-cross' twins of pyrite are reported to occur in reduced pale-green Triassic calcareous claystones and marls (Jochum et al., 1995; Jahn, 2001). In skarn-hosted Fe-deposits at Rio Marina, pyrite occurs in an association with Feoxides. In the study of the paragenetic sequence of this deposit, Cocco and Garavelli (1954) showed that primary hematite ore was reduced by the introduction of sulfide-bearing solutions. Reduction of hematite is evident from the lamellar habit of magnetite, followed by abundant crystallization of pyrite and minute quantities of other sulfides (Tanelli et al. 2001).

In the present study of the origin of 'iron-cross' twinning of pyrite we selected a small sedimentary occurrence on northern slopes of Mt. Katarina (NW of Ljubljana in Slovenia) with a simple mineralization sequence (Mlakar, 2002a; Mlakar, 2002b). This belongs to the Val Gardena (Upper Permian) red-bed type deposits that were investigated intensely for economic reserves of uranium and copper (Houten, 1973; Budkovič, 1981). The sediments of the Val Gardena formation are of alluvial origin, interrupted occasionally by shallow marine sedimentation (Skaberne, 1981; Dolenec, 1983). They consist of oxidized purple-red siltstone with lenses of colourful unlithified, and partially silicified, reduced (grey, light green, pink or yellow) marls (Mlakar, 2002a), containing authigene pyrite mineralization (Dobrač stratum). The boundary between oxidized and reduced beds is sharp and is caused by a chemical reduction of the stratum (Budkovič, 1981; Zavašnik, 2009). Pyrite mineralization is confined strictly to reduced layers, wherein the occurrence of twinned crystals is restricted to bands of pink colouration (Mlakar, 2002b; Rečnik, 2007).

To resolve the geochemical conditions for the formation of twinned pyrite crystals, special attention was dedicated to the initial stages of the reduction processes that led to the formation of pyrite. A mineralization sequence was determined using sulfur isotope measurements and electron microscopy methods. The phase composition of the inclusions and local chemistry of the interfaces in twinned pyrite crystals were investigated down to sub-nanometre scale.

\section{Experimental methods}

Samples of oxidized and reduced sediment were collected carefully from freshly opened outcrop (Zavašnik, 2009). Dried sediment was ground and analysed by powder X-ray diffraction (XRPD; PW 3830/40, PANalytical B.V., Almelo, the Netherlands) to determine its phase composition. Mineral associations, crystal morphology and overgrowths of the minerals in the samples were further studied by scanning electron microscopy (SEM; JSM-5800, Jeol Inc., Tokyo, Japan) equipped by an energy-dispersive X-ray spectrometer (EDS; Oxford Instruments Model 6841, Oxford Instruments PLC, Oxfordshire, UK). Reduced sediment, containing twinned pyrite crystals (Fig. 1), was dried and washed on a sieve. The pyrites are lustrous, with no signs of alteration, ideal for geochemical studies. Their morphology is dominated by pentagon-dodecahedral $\{210\}$, hexahedral $\{100\}$ and octahedral $\{111\}$ forms (Rečnik, 2007). Silicified nodules containing clastic material and pyrite crystals were cut and polished for cross-sectional observations, whereas the fine fraction was studied using an optical microscope for accessory minerals. The sulfur isotope ratios ${ }^{34} \mathrm{~S} /{ }^{32} \mathrm{~S}$ were measured using a mass spectrometer (PDZ Europa 20-20, Europa Scientific, Crewe, UK) equipped with an automated sampler (ANCA-SL, SerCon Ltd., Cheshire, UK) according to a standard analytical procedure (see e.g. Seal, 2006). The ratio of sulfur isotopes is expressed relative to the $\mathrm{S}$ isotope ratio for meteoritic sulfur, as a $\delta^{34} \mathrm{~S}$ value, defined by Thode et al. (1961). Troilite from the Canyon Diablo meteorite with $\delta^{34} \mathrm{~S}=0 \%$ was used as a reference and IAEA S-1, IAEA S-2 and IAEA S-3 materials with known isotopic compositions were used as standards (Coplen and Krouse, 1998).

For TEM observations the crystals were mounted into $3 \mathrm{~mm}$ brass rings oriented along the [001]-axis to study the twin boundaries lying in $\{110\}$ and $\{100\}$ planes. The TEM sample was cut close to the centre of the crystal to investigate the twin nucleation point. The specimen was thinned to $100 \mu \mathrm{m}$ and dimpled down to $20 \mu \mathrm{m}$ at the disc 

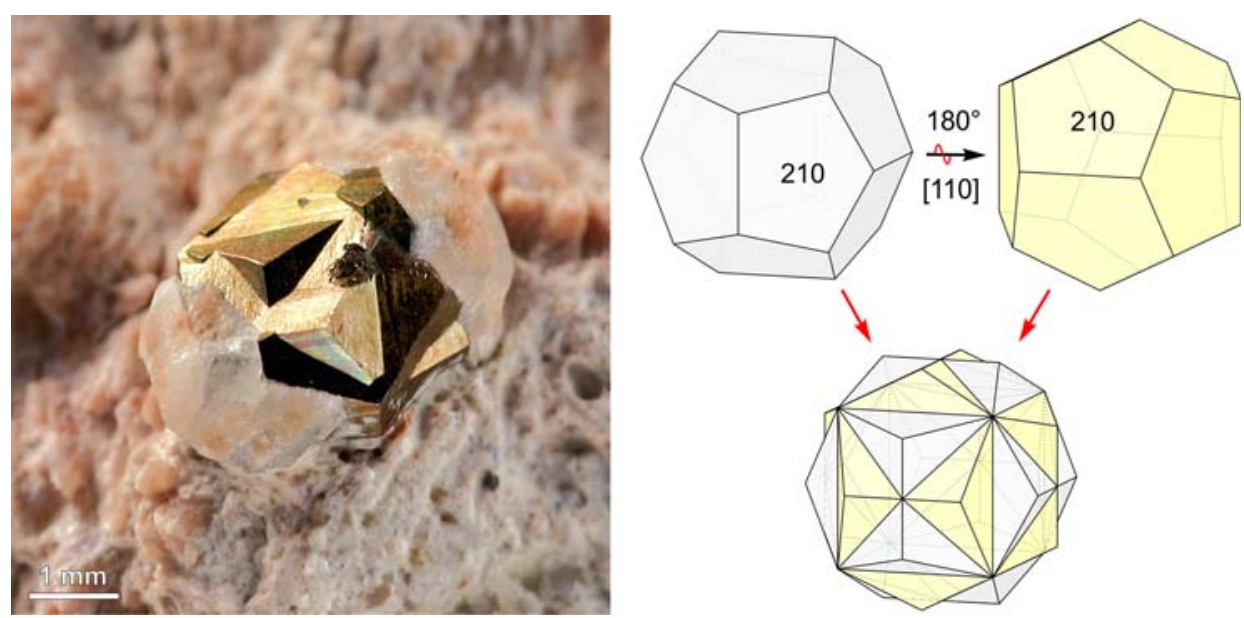

Fig. 1. 'Iron-cross' twin of pyrite with translucent quartz caps (covering the twin at bottom-left and top-right) in unlithified pink coloured marl from Mt. Katarina, Slovenia. The microphotograph (Canon EOS 300D) was recorded using the focus-stack method with the [111] axis parallel to the camera optical axis and illuminated at three acute angles near total reflectance of the selected (210) faces. Compared to these faces un-illuminated faces appear dark, producing a striking effect of two interpenetrating pyritohedra. The drawing on the right illustrates the crystallographic operation involved in $\{110\}$ twinning of pyrite.

centre (Dimple grinder 656, Gatan Inc., Pleasanton, USA). After grinding the sample was ion milled (RES 010, Bal-Tec A.G., Balzers, Liechtenstein) at an incidence angle of $10^{\circ}$, using $4 \mathrm{kVAr}^{+}$ions until the central part of the TEM specimen was perforated. To improve surface electron conductivity, the specimen was coated with a $3 \mathrm{~nm}$ thick carbon layer (PECS 682, Gatan Inc., Pleasanton, USA). Inclusions and interfaces in twinned pyrite crystals were studied using a $200 \mathrm{kV}$ field-emission gun (FEG) transmission electron microscope (TEM/STEM; JEM-2010F (JSI), Jeol Inc., Tokyo, Japan), enabling high-resolution imaging in scanning mode and chemical analyses with a subnanometre spatial resolution. The microscope is equipped with a high-angle annular dark-field detector (HAADF; EM-24140 YDF-Yap, Jeol Inc., Tokyo, Japan) and an EDS detector (Oxford Instruments Link ISIS 300, Oxford Instruments PLC, Oxfordshire, UK). To prevent interaction of stray electrons and $\mathrm{X}$-rays (from the column and the specimen, e.g. inclusions from the surroundings of the analysed region, brass ring) with the incident electron beam, the top-hat aperture was used during the EDS analysis. The EDS elemental mapping was performed at an accelerating voltage of $200 \mathrm{kV}$ in ER-C (Titan G2 80-200 ChemiSTEM (ER-C), FEI, Netherlands) and processed within Bruker Esprit software. The microscope is equipped with a highbrightness Schottky FEG, a spherical aberration (Cs) corrector for the probe-forming part (DCOR, CEOS GmbH, Germany), a HAADF detector (Model 3000, Fischione Instruments, USA) and a super-X EDS system (Quantax, Bruker Nano $\mathrm{GmbH}$, Berlin, Germany). The EDS system with $4 \times 30 \mathrm{~mm}^{2}$ windowless silicon drift detectors (SDDs) is designed for fast acquisition of EDS maps.

\section{Results and discussion}

The narrow grain-size distribution of oxidized and reduced strata suggests that the primary clastic material was deposited in an identical environment (Zavašnik, 2009). X-ray diffraction analysis of both oxidized and reduced parts of the sediment show the same mineralogical composition of the primary clastic components. Lithic grains are dominated by quartz, plagioclase, muscovite and illite, which are accompanied by minor amounts of zircon, tourmaline, rutile and apatite. While grain size distribution is rather narrow (well sorted), the primary clastic material shows different degrees of abrasion, suggesting a relatively broad sedimentation background (Skaberne, 1981; Mlakar, 2002b). 


\section{Mineralization processes and reduction of the stratum}

The main diagenetic mineral in the Dobrač red-bed stratum is hematite, which occurs in the form of thin leafy crystals (Fig. 2a), suggesting authigenic crystallization during sedimentation in oxidizing conditions (Walker et al., 1980). In addition to hematite, which is responsible for the colouration of the red-beds, Fe-rich clinochlore is also present. Sedimentary chlorites are formed under the conditions of moderate burial at temperatures up to $150^{\circ} \mathrm{C}$, principally at the expense of kaolinite and carbonate minerals (dolomite, ankerite) and illitization of clay minerals (Curtis et al., 1985). The $\mathrm{Fe}^{2+}$ and $\mathrm{Mg}^{2+}$ released during illitization are the key reactants in chlorite formation, together with reduction of hematite causing the increase of alkalinity. Reduction of iron is accompanied by co-precipitation of ankerite (Curtis et al., 1985). In both types of the sediment, oxidized and reduced, Fe-rich dolomite is present in the form of euhedral grains that suggest its authigenic crystallization during diagenesis.

Chemical reduction and discolouration of the red-beds was caused by the inflow of reducing sulfide-rich solutions along the more permeable layers. The onset of reduction at the Mt. Katarina locality is characterized by the presence of euhedral magnetite crystals (Fig. 2b), that were found in the heavy fraction of pink-coloured bands of the reduced parts of the stratum, containing the pyrite twins. Magnetite crystals have overgrown the primary lithic grains (e.g. zircon) and show no visible traces of abrasion. Etch-pits resulting from corrosion in the increasingly acidic environment can be observed on some crystals. The amount of magnetite is very low relative to pyrite, implying a relatively short period of its crystallization. With increasing concentration of sulfide ions in the solution $\mathrm{Fe}^{3+}$ is reduced to $\mathrm{Fe}^{2+}$ and instead of magnetite, pyrite starts to form (Canfield and Berner, 1987), possibly replacing magnetite. Crystallization of magnetite and pyrite can be explained by the reduction of hematite that is present in the primary oxidized sediment:

$$
2 \cdot \mathrm{Fe}_{2} \mathrm{O}_{3}+2 \cdot \mathrm{H}_{2} \mathrm{~S} \rightarrow \mathrm{Fe}_{3} \mathrm{O}_{4}+\mathrm{FeS}_{2}+2 \cdot \mathrm{H}_{2} \mathrm{O}
$$

A similar reduction process that takes place with the onset of reducing conditions has been described in other types of hematite deposits (e.g. in skarns; Cocco and Garavelli, 1954).

\section{Authigenic crystallization of pyrite and the origin of sulfur}

Reduced layers of the Dobrač stratum are characterized by green colouration, presence of euhedral pyrite crystals and partial silicification (Mlakar, 2002a; Mlakar 2002b), similar to that of the Triassic marls in the Vlotho area (Jahn, 2001). While most of the reduced layers were deformed and altered in subsequent tectonic and diagenetic processes, fractions of clastic material with pyrite crystals in their original state are best preserved within the quartz nodules, which formed during the diagenesis that followed the pyrite crystallization. These nodules are most suitable for investigations of relative dependencies between the primary minerals. Cross-sections of the nodules containing primary minerals that formed in the reduced sediment at different stages of recrystallization are shown in Fig. 3. They reveal that sulfide mineralization starts by dissolution of ankerite and its replacement by dolomite and, at the same time, replacement of the Fe-rich carbonate core is accompanied by pyrite crystallization (Fig. $3 a$ ). Simultaneous dolomite and pyrite growth continues until the Fe-rich core is completely replaced by dolomite and finely crystalline pyrite (Fig. $3 b$ ).

Decomposition of the primary ferroan dolomite (ankerite) to dolomite and pyrite suggests that a change in geochemical conditions in this crystallization period is related to the inflow of sulfur-rich solutions:

$$
\begin{aligned}
& 2 \cdot \mathrm{Ca}(\mathrm{Fe}, \mathrm{Mg})\left(\mathrm{CO}_{3}\right)_{2}+2 \cdot \mathrm{S}^{1^{-}} \\
& \rightarrow \mathrm{CaMg}\left(\mathrm{CO}_{3}\right)_{2}+\mathrm{FeS}_{2}+\mathrm{CaCO}_{3}+\mathrm{CO}_{3}^{2^{-}}
\end{aligned}
$$

To differentiate further between different types of pyrite crystals and understand the migration of the reduction boundary in the reduced Dobrač stratum, we measured the ${ }^{34} \mathrm{~S} /{ }^{32} \mathrm{~S}$ isotope ratio. Normal isotopic values in red-bed type $\mathrm{Cu}$ and $\mathrm{U}$ deposits show a wide range in $\delta^{34} \mathrm{~S}$ from 0 to $-50 \%$, while pyrite samples from the Žirovski Vrh uranium deposit in the vicinity of Mt. Katarina show a distribution between -14 to $-45 \%$ (Dolenec, 1983). The results of sulfur isotope measurements of the pyrite samples from Mt. Katarina show that they are all enriched with the heavy $\mathrm{S}$ isotope in comparison to the pyrite from the nearby uranium deposit and show $\delta^{34} \mathrm{~S}$ values between 0 and $-8 \%$ (Table 1).

The possibility of the bacterial origin of sulfur can be excluded because biogenic pyrite has highly positive $\delta^{34} \mathrm{~S}$ values (Drake, 2013) and also, 

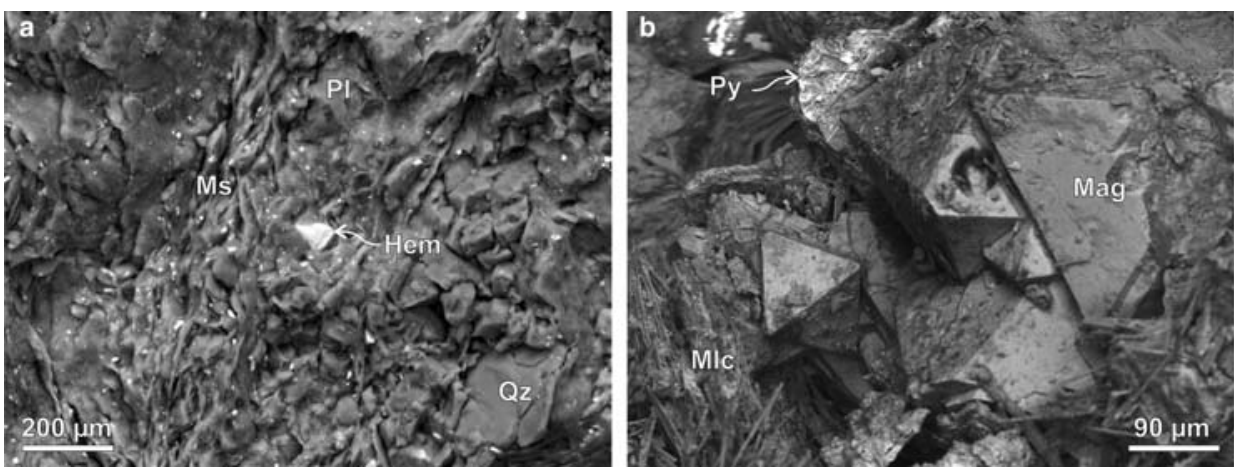

FIG. 2. Back-scattered SEM images of ( $a$ ) oxidized sediment composed of lithic grains of quartz (Qz), plagioclase (Pl) and muscovite (Ms) with leafy hematite (Hem) displaying an intense white contrast due to its higher scattering potential. (b) Euhedral magnetite (Mag) crystals partially overgrown by pyrite (Py) and malachite (Mlc) from the reduced stratum. Malachite is a result of epigenetic oxidation processes and suggests the presence of other $\mathrm{Cu}$ minerals in the mineralized stratum.

because no framboidal pyrite was found in our samples (Folk, 2005). According to Cheney and Jensen (1966) lighter isotopes react prior to the heavier $\mathrm{S}$ isotopes during crystallization of pyrite due to strong chemical fractionation. Results from the St. Katarina locality suggest that most of the light ${ }^{32} \mathrm{~S}$ isotope was already depleted at the primary source of sulfur (Zavašnik, 2009) and thus sulfur, enriched in the heavier ${ }^{34} \mathrm{~S}$ isotope, remained for the formation of authigenic pyrite crystals in the Mt. Katarina stratum. A similar fractionation process apparently also influenced the
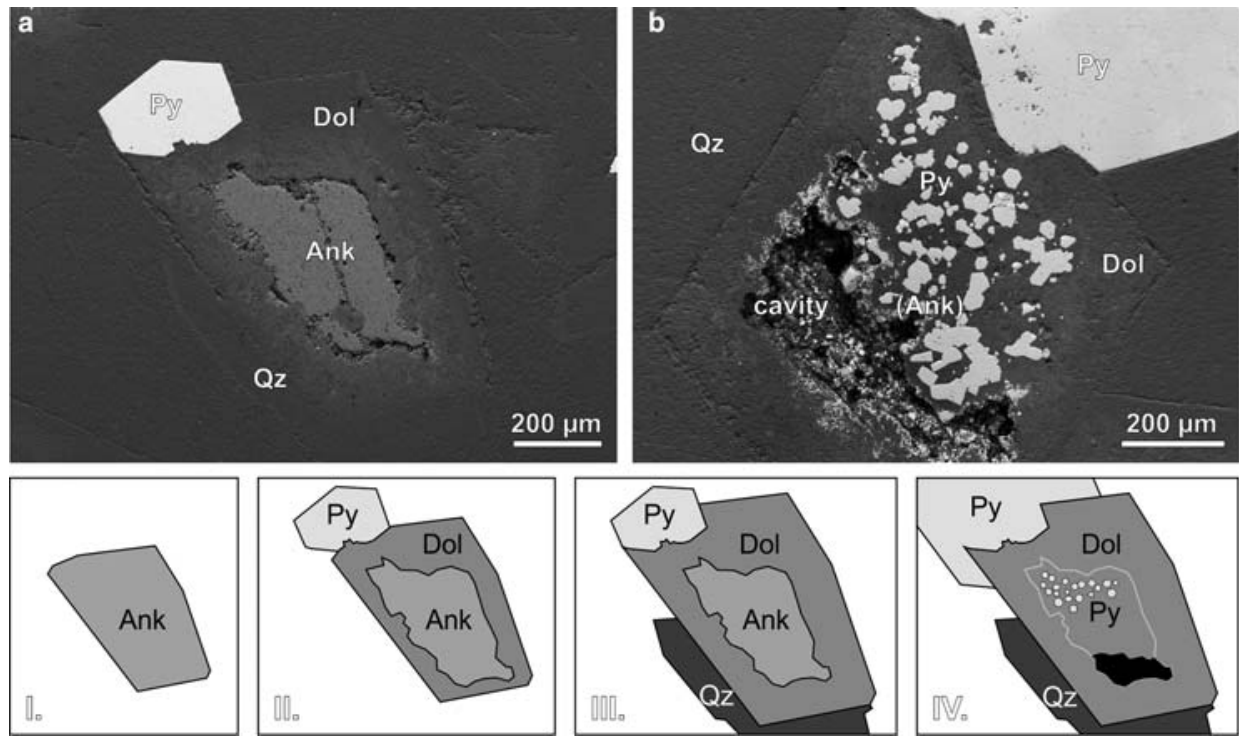

Fig. 3. Back-scattered SEM images of polished cross-sections of quartz nodules from the reduced sediment showing relations between minerals prior to the crystallization of quartz (Qz). (a) Dolomite (Dol) crystal with corroded ferrian dolomite or ankerite core (Ank). Pyrite (Py) started to crystallize at the end of dolomite growth. (b) Ankerite completely recrystallized to dolomite and younger generation of pyrite. The illustration shows the four stages of recrystallization of primary ankerite. 
TABLE 1. Crystal habits and their average sizes with increasing depth from the oxidation-reduction $(\mathrm{O}-\mathrm{R})$ boundary at the Mt. Katarina locality.

\begin{tabular}{lcccc}
\hline Site & Depth $[\mathrm{cm}]$ & Crystal habit & Crystal size $[\mathrm{mm}]$ & $\delta^{34} \mathrm{~S}[\% 0]$ \\
\hline 1 & 5 & $\{120\}$ & 10 & $+0.2 \pm 0.4$ \\
2 & 80 & $\{100\},\{120\}$ & 5 & $-8.4 \pm 0.5$ \\
3 & 120 & $\{120\},\{100\}$ & 6 & $-6.8 \pm 0.4$ \\
4 & 140 & $\{120\},\{100\}$ & 5 & $-7.3 \pm 0.7$ \\
5 & 200 & $\{120\}$, twins & 4 & $-4.1 \pm 0.6$
\end{tabular}

(1) White un-lithified clay containing large oxidized pyrite crystals; (2) partly lithified light-brown quartz sandstone and marl with partially oxidized hexahedral pyrite crystals; (3) light-grey un-lithified claystone with fresh pentagon-dodecahedral crystals of pyrite, modified by hexahedral facets; (4) light-green un-lithified claystone with fresh pentagon-dodecahedral crystals; and (5) light-pink partly silicified marly sandstone with twinned pyrite crystals. The corresponding $\delta^{34} \mathrm{~S}$ isotope values were measured according to Thode et al. (1961), using IAEA S-1, IAEA S-2 and IAEA S-3 standards (Coplen and Krouse, 1998).

mineralization inside the investigated stratum and explains why the large crystals near the oxidationreduction $(\mathrm{O}-\mathrm{R})$ boundary (Site 1, Table 1) display the highest $\delta^{34} \mathrm{~S}$ values.

The ${ }^{34} \mathrm{~S} /{ }^{32} \mathrm{~S}$ isotope analysis suggests that the primary source of sulfur was a sulfide orebody in the vicinity, possibly Knapovže (Mlakar, 2002a), where most of the lighter ${ }^{32} \mathrm{~S}$ isotope was consumed and the remaining fluids, rich in the heavier ${ }^{34} \mathrm{~S}$ isotope, were available for partial reduction of the stratum and authigenic crystallization of pyrite.

\section{Geochemical environment during the growth of pyrite crystals}

To check for the presence of other elements (in addition to $\mathrm{S}$ ) that were mobilized into the stratum together with the reducing fluids and influenced the crystallization of pyrite, we analysed the inclusions in pyrite crystals by SEM and TEM methods.

Protogenetic inclusions in the interior of the pyrite crystals and syngenetic inclusions located close to their surface are shown in Fig. 4. In cross-
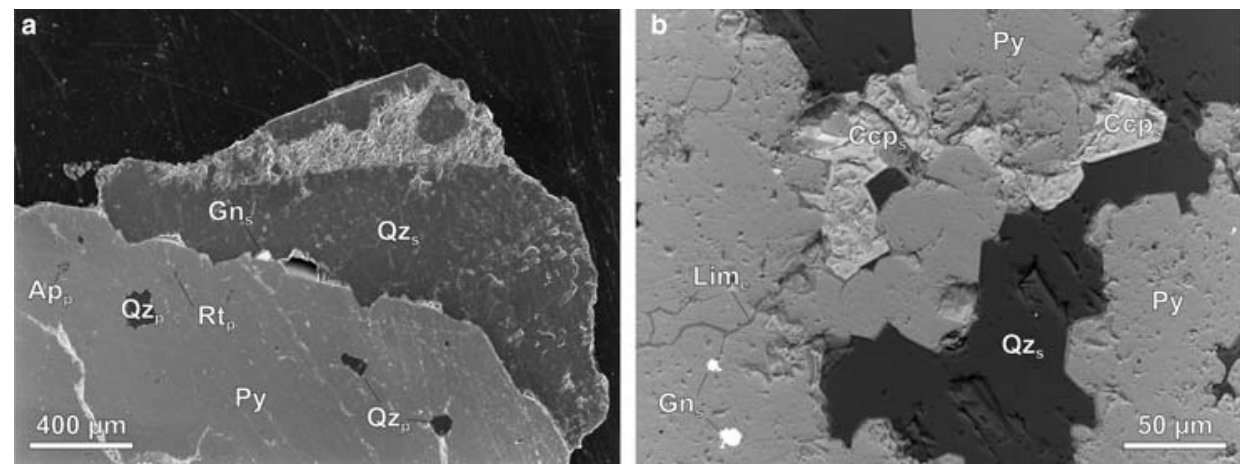

FIG. 4. Back-scattered SEM images of polished cross-sections of pyrite crystals from the reduced stratum containing different types of inclusions (protogenetic and syngenetic) and quartz caps in 'pressure-shadows'. (a) Pyrite (Py) with protogenetic inclusions of quartz $(\mathrm{Qz} p)$, rutile $\left(\mathrm{Rt}_{\mathrm{p}}\right)$ and apatite $\left(\mathrm{Ap}_{\mathrm{p}}\right)$. At the interface of a pyrite crystal with a syngenetic quartz-cap $\left(\mathrm{Qz}_{\mathrm{s}}\right)$ the crystallization of syngenetic galena $\left(\mathrm{Gn}_{\mathrm{s}}\right)$ is observed. (b) Detail from the pyrite-quartz interface showing simultaneous crystallization of syngenetic galena $\left(\mathrm{Gn}_{\mathrm{s}}\right)$, chalcopyrite $\left(\mathrm{Ccp}_{\mathrm{s}}\right)$ and quartz $\left(\mathrm{Qz}_{\mathrm{s}}\right)$. Feoxyhydroxides $\left(\operatorname{Lim}_{\mathrm{e}}\right)$ filling the cracks in pyrite belong to a younger epigenetic oxidative processes. 
sections of pyrite crystals the most commonly observed protogenetic inclusions are grains of quartz, feldspars, rutile, zircon, mica and apatite (Fig. 4a). These inclusions usually do not exceed $100 \mu \mathrm{m}$. Inclusions of mica are commonly oriented parallel to the faces of the pyrite crystal, indicating that they were aligned in the diffusion zone at the surface of the pyrite crystal to minimize the surface energy before they were finally overgrown. More interesting, however, are the syngenetic inclusions of the minerals that crystallized at the end of the pyrite growth period. These syngenetic inclusions are best preserved under quartz caps covering the pyrite crystals (Fig. 4b). Among these, galena $(\mathrm{PbS})$, chalcopyrite $\left(\mathrm{CuFeS}_{2}\right)$ and quartz were confirmed by EDS analysis. In chalcopyrite, copper sulfide grains with an increased amount of As were detected, having compositions approaching that of enargite. A similar association with minor $\mathrm{Cu}$ mineralization (chalcopyrite, malachite) is also reported from pyrite-bearing light-green marls in Weserbergland, Germany (Jochum et al., 1995; Jahn, 2001). Syngenetic quartz $\left(\mathrm{Qz}_{\mathrm{s}}\right)$ was deposited on pyrite towards the end of its growth. Pyrite growth was accompanied by tectonic deformation and folding of the stratum, which caused partial dissolution of lithic quartz and its authigenic growth in pressure-shadows around pyrite crystals (Pabst, 1931) in the form of quartz caps (Fig. 1). A cross-section of an epigenetic quartz cap $\left(\mathrm{Qz}_{\mathrm{e}}\right)$, grown in such shadows, is shown in Fig. $4 a$.

\section{Geochemical conditions for the formation of twin boundaries in pyrite}

Twinned pyrite crystals were investigated further by TEM. A low-magnification bright-field (BF) STEM image of twinned pyrite in [001] orientation is shown in Fig. $5 a$. The pyrite crystal contains many inclusions of muscovite, rutile, zircon, apatite, dolomite and quartz. The twin boundary is characterized by a wavy bright line crossing the area. Electron diffraction acquired from the boundary shows a characteristic twin-pattern with combined reflections from both pyrite domains, translated by $180^{\circ}$ rotation around the [110] twin axis. Its contrast arises from the diffraction contrast of overlapping domains, and does not reflect possible variations in chemistry.

Variations in composition can be studied in STEM mode by collecting incoherently scattered electrons, out of the range of the Bragg diffraction, using annular detectors. While at medium collection angles (MAADF; $>50 \mathrm{mrad}$ ) the image contrast is dominated by inelastic thermal diffuse scattering (TDS), at higher collection angles (HAADF; $60-180 \mathrm{mrad}$ ) the image contrast is dominated by incoherent elastic Rutherford scattering that carries the information on average atomic density of the sample (Z-contrast). Under these conditions, muscovite and rutile that have lower atomic density appear darker than pyrite, and the phases with higher average atomic number appear bright. Therefore under the BF conditions muscovite appears white, whereas in HAADF, it is black because of its lower atomic density. Some inclusions with poor wetting to pyrite show few nanometres thick amorphous layers with an intense bright contrast. Bright contrast visible around the rutile inclusion, shown in Fig. $5 c$, results from the presence of heavier elements, such as $\mathrm{Pb}, \mathrm{As}$ and $\mathrm{Cu}$ (Fig. 5d). These elements do not form any particular phase but constitute an $\sim 2-\mathrm{nm}$ thick amorphous layer around the inclusion, indicating a residue of mineralizing fluids entrapped along with the inclusions during pyrite growth. Based on this nanogeochemical evidence it appears that $\mathrm{Pb}$ - and $\mathrm{Cu}$-rich solutions were already present during the nucleation of twinned pyrite and crystallized as galena and chalcopyrite just before the end of the pyrite crystallization sequence (see Fig. 4). Copper- and $\mathrm{Pb}$-enriched pyrites have also been reported from other sulfide deposits (Pačevski et. al 2008; Cabral et al., 2011).

In the HAADF-STEM image in Fig. $5 b$ the twin boundary is slightly more intense than the pyrite matrix, which may indicate the presence of heavier elements. However, we must consider that a similar variation of intensity might result from a residual diffraction contrast of two interfering structures. The possibility of different chemical compositions on the twin boundary must therefore be confirmed spectroscopically. The EDS analyses on random locations along the twin boundary indicate the presence of $\mathrm{Cu}$, suggesting that the formation of twin boundaries might be chemically triggered. As $\mathrm{Cu}$ is slightly heavier than $\mathrm{Fe}$, this could be the reason for the higher intensity of the twin boundary in the Z-contrast image (Fig. 5b). Enrichment of Cu on the twin boundary was studied additionally by EDS mapping of $\mathrm{Fe} K, \mathrm{Cu} K$ and $\mathrm{S} K$ line signals, which showed that the increase of $\mathrm{Cu}$ along the twin boundary is accompanied by a deficiency in Fe, whereas the concentration of $\mathrm{S}$ remains constant (Fig. 6). To ensure sufficient signal, EDS maps were performed on the thicker part of the crystal, 

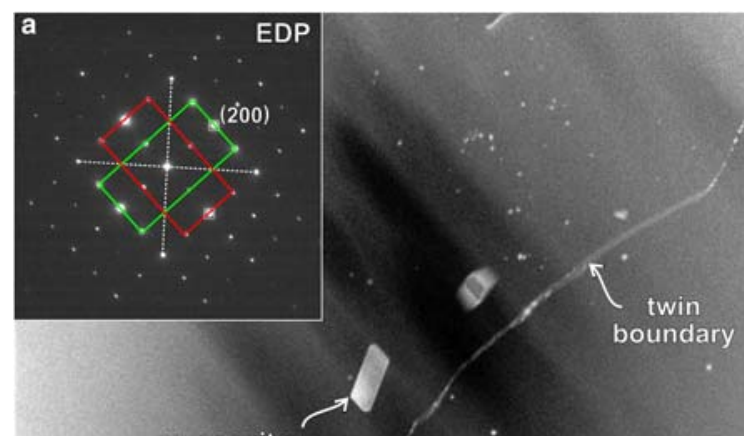

muscovite
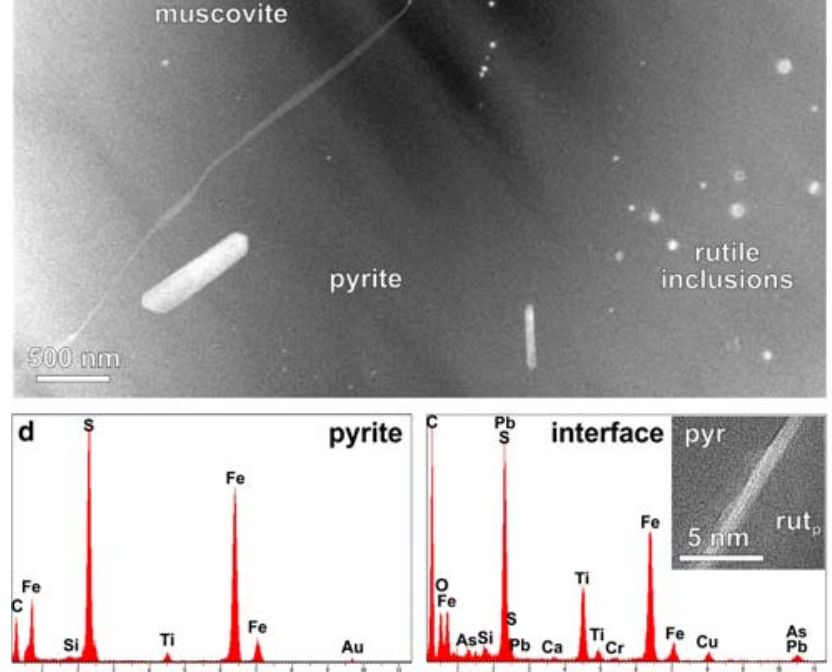

pyrite
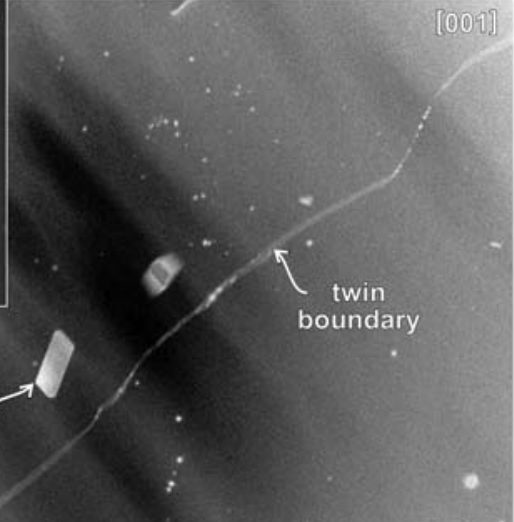

;
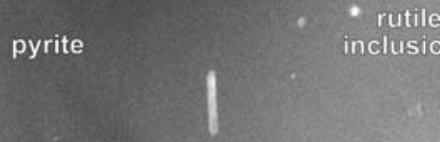
inclusions

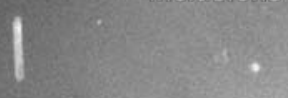

FIG. 5. Scanning TEM study of inclusions and interfaces in twinned pyrite crystals. (a) BF-STEM image displaying a twin boundary (wavy line crossing the imaged area) and protogenetic inclusions of muscovite and rutile with an electron diffraction pattern (EDP; inset) recorded across the twin boundary in the [001] zone axis. In this section the general crystal direction of the twin boundary roughly coincides with (010) plane. Dotted lines in the EDP indicate $\{110\}$ planes. (b) HAADF-STEM image of the twin boundary (TW) with a large muscovite inclusion. (c) HAADF-STEM of a rutile inclusion with white upper rim, caused by the presence of heavy elements, with $(d)$ corresponding EDS spectra confirming an enrichment with $\mathrm{Pb}, \mathrm{Au}, \mathrm{As}, \mathrm{Cu}, \mathrm{Cr}, \mathrm{Ca}, \mathrm{Si}$ and $\mathrm{Mg}$ in the amorphous layer along the rutile-pyrite interface. The twin boundary is enriched in $\mathrm{Cu}$.

where the count rate was high enough $(\sim 1300$ counts/s) to acquire maps in short acquisition times (5 min) to minimize possible specimen drift and contamination. Greater thickness inevitably led to beam spreading, which in effect additionally lowered the spatial resolution of the EDS maps. Because of beam spreading and sample drift the effective width of the twin boundary appears larger than what would be expected from the boundary contrast of the HAADF-STEM image.

To understand the role of $\mathrm{Cu}$ in twin formation, it is important to determine accurately the concentration of $\mathrm{Cu}$ at the twin boundary. A close inspection of the twin boundary reveals that the wavy twin boundary is composed of two types of interfaces: one following $\{110\}$ planes (type-A), and another along $\{100\}$ planes (type-B), producing complex 3D interpenetration twinning. Fig. $7 a$ shows a HRTEM image of an alternating twin interface between two pyrite domains from the central section of the crystal viewed in [001] projection. The boundary makes steps from the $\{110\}$ to $\{100\}$ planes, some of which are edge-on, and others inclined. In total, there are six sets of type-A and three sets of type-B twin boundaries alternating along the interface, whereas the crystallographic relation between the twinned domains remains identical throughout. In [001] projection for example, we can observe a 

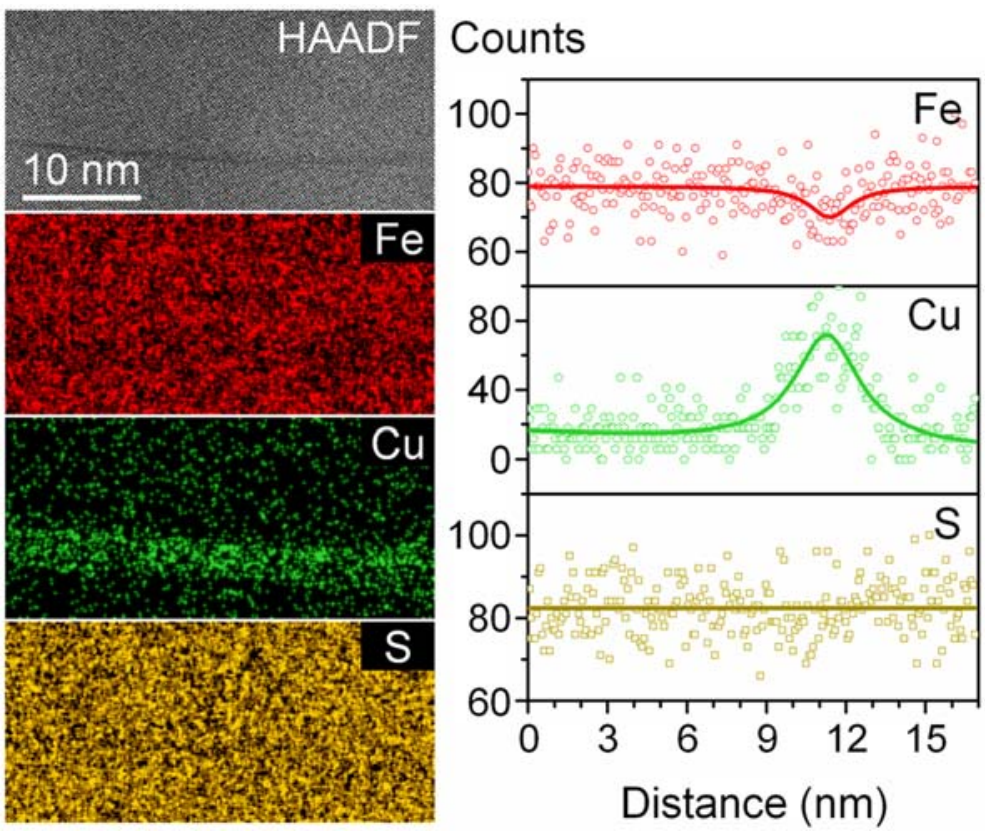

FIG. 6. HAADF-STEM image with corresponding EDS elemental maps of $\mathrm{Fe} K$ (red), $\mathrm{Cu} K$ (green) and $\mathrm{S} K$ (yellow) line signals recorded across a $\{110\}$ twin boundary of pyrite. The mapping reveals Fe deficiency and $\mathrm{Cu}$ enrichment, while the amount of S remains constant (left panel). The element distribution is best demonstrated by integrated line profiles of total counts for individual elements (right panel). To ensure a sufficient count-rate EDS mapping was performed in the thicker part of the crystal resulting in apparent boundary broadening.

maximum of two sets of type-A, i.e. (110) and $(1 \overline{1} 0)$, and two sets of type-B interfaces, i.e. (100) and (010), with their counterparts in an edge-on orientation that are suitable for quantitative HRTEM and EDS analysis, whereas the rest of the variants are inclined in this projection. Without the type-B boundaries, iron-cross twins of pyrite would be perfectly symmetrical, however this is never the case. Therefore during TEM work one has to be careful when analysing the twin boundaries, as the inclined boundaries (including the component of the zone-axis vector) are statistically more frequent than the edge-on boundaries. The steps between the two twin types can be several nanometres long and there is no rule as to the length of individual segments. In idealized symmetric interpenetration twins, the type-A boundary is a simple linear combination of type-B twins (illustrated in Fig. 7b):

$$
a \cdot(100)+b \cdot(010) \rightarrow(110)
$$

where $a=b$, whereas in the case of realistic twins $a \neq b$.
The higher probability of observing an inclined section of the interface explains why Donnay et al. (1977) studied an inclined twin boundary. The crystallographic complexity of an alternating twin interface must have a simple thermodynamic explanation. We noticed that with the distance from the centre of the crystals the frequency of typeA twin segments decreases, while the type-B sections become dominating. The EDS analysis shows that the two boundaries have a distinctly different composition. While the type-A twin boundaries comprise significant amounts of $\mathrm{Cu}$, type-B twin boundaries, similar to bulk pyrite, appear to be devoid of $\mathrm{Cu}$ (Fig. 7c). The amount of $\mathrm{Cu}$ on type-A twin boundaries is constant and stems exactly from the twin interface. For quantitative analysis we used a concentric electron probe (CEP) method that was particularly designed for measurement of dopant elements on twin boundaries and interfaces (Rečnik et al., 2001; Walther et al., 2004). The intensity ratio between the dopant $(\mathrm{Cu})$ and matrix element $(\mathrm{Fe})$ is directly proportional to the volume of analysis according to the following 

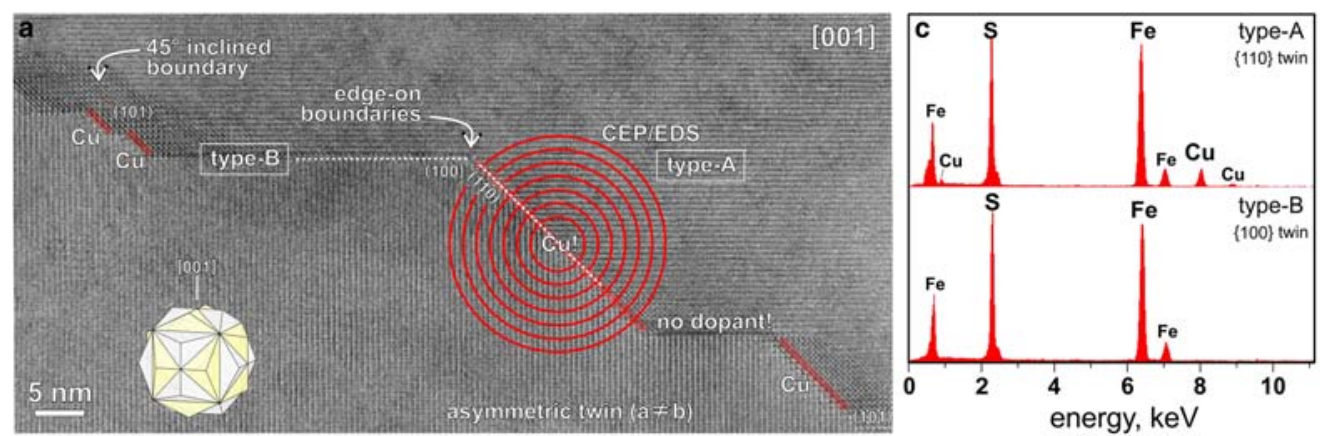

b
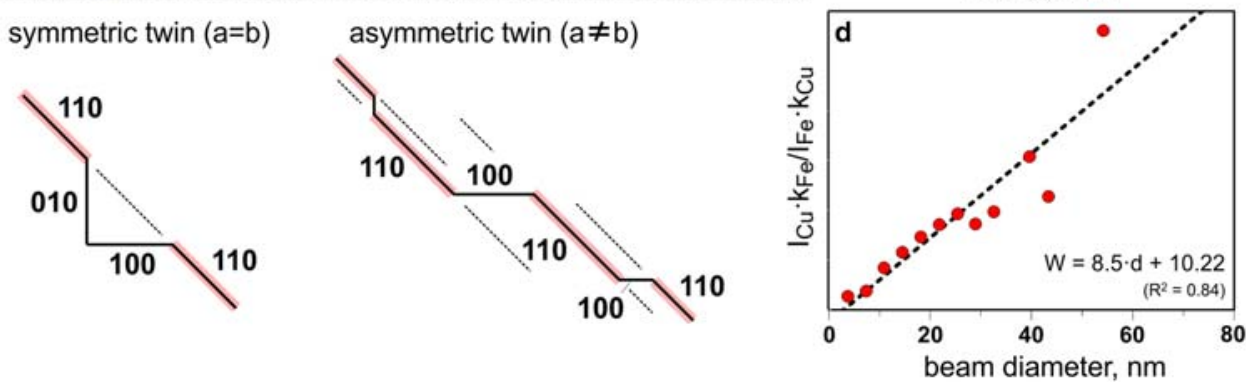

FIG. 7. TEM analysis of twin boundaries in an iron-cross twin of pyrite. (a) HRTEM image of two types of thermodynamically stable twin boundaries in pyrite: type-A in $\{110\}$ planes, and type-B in $\{100\}$ planes. $(b)$ Illustration of symmetrical and asymmetrical twin boundaries produced by a linear combination of type-A and type-B twin boundaries. (c) EDS analysis of the two types of twin boundaries. Note that only type-A twin boundaries are enriched in $\mathrm{Cu}$, whereas type-B boundaries are pure. (d) Quantitative concentric electron probe EDS analysis (CEP/EDS) of the type-A twin boundary; illustrated in $(a)$.

linear dependence:

$$
W=\frac{I_{\mathrm{Cu}} \cdot k_{\mathrm{Fe}}}{I_{\mathrm{Fe}} \cdot k_{\mathrm{Cu}}}=\frac{\pi}{2 \delta} \cdot d+\text { const. }
$$

where $W$ is the intensity ratio, $I_{\mathrm{Fe}}$ and $I_{\mathrm{Cu}}$ are count rates for measured elements, $k_{\mathrm{Fe}}$ and $k_{\mathrm{Cu}}$ are EDS $k$-factors (Cliff and Lorimer, 1975; procedures for determination: Rečnik et al., 2001 and Walther et al., 2004), $d$ is beam diameter and $\delta$ is the apparent boundary width occupied by the dopant element assuming the same structural density as the matrix element. The calculated boundary width for $\mathrm{Cu}$ from multiple EDS measurements (Fig. $7 d$ ) suggests that it occupies $0.18 \pm 0.03 \mathrm{~nm}$ of the typeA interface, which would correspond to about one (220) layer of $\mathrm{Cu}$.

Based on our chemical and structural analysis we demonstrated that the formation of symmetric $\{110\}$ twin boundaries (type-A) in pyrite is triggered chemically. This suggests that in the presence of $\mathrm{Cu}$ type-A twin boundaries are thermodynamically stable, whereas in the absence of $\mathrm{Cu}$ the more stable configuration is a type-B interface. The
$\mathrm{Cu}$-rich type- $\mathrm{A}$ interfaces are therefore the primary twin boundaries that are responsible for the formation of iron-cross twins, whereas the type-B interfaces are secondary twin boundaries, which form as a result of parallel growth of twinned domains, when the source of $\mathrm{Cu}$ in the surrounding fluids is interrupted. Similar observations on chemically induced twinning have been reported in other minerals (Daneu and Rečnik, 2012) such as in O-rich twin boundaries in sphalerite (Šrot et al., 2003) and Be-rich twin boundaries in spinel (Daneu et al., 2007; Drev et al., 2013). Considering a similar mineralization sequence (Canfield and Berner, 1987) and the presence of $\mathrm{Cu}$ minerals on other occurrences of twinned pyrite (Jochum et al., 1995; Cocco and Garavelli 1954), we believe that twinning in pyrite is generally related to the reduction of primary Feoxides in the presence of $\mathrm{Cu}$-rich fluids.

\section{Conclusions}

The origin of iron-cross twins in pyrite was studied from a small occurrence on Mt. Katarina, near Ljubljana in Slovenia. The mineralization is located 
in partially silicified sandy-silt sediment that was deposited in an Upper Permian oxygen-rich freshwater environment, indicated by the presence of hematite. In a subsequent inflow of sulfide-rich fluids from a neighbouring sulfide deposit the primary red-coloured hematite-rich sediment was reduced and geochemical conditions suitable for sulfide mineralization were created. The mineralization began with decomposition of hematite, $\mathrm{Fe}$ carbonates and clay minerals. With the onset of $\mathrm{Fe}^{3+}$ reduction, magnetite crystallized for a short period, which was soon followed by an abundant pyrite and minor chalcopyrite and galena mineralization. Sulfur isotope analyses of pyrite crystals showed enrichment in the heavier $\delta^{34} \mathrm{~S}$ isotope suggesting a strong chemical fractionation of sulfur. Nanoscale studies of interfaces between protogenetic inclusions and the pyrite matrix confirmed that $\mathrm{Pb}, \mathrm{As}$ and $\mathrm{Cu}$ were present in the solutions throughout the pyrite crystallization period. Using TEM methods we demonstrated that $\{110\}$ twin boundaries consistently show enrichments in $\mathrm{Cu}$, while other impurity elements, apparently present in the environment, do not get incorporated. This finding suggests that $\mathrm{Cu}$ has been involved in the nucleation of (110) twin boundaries in pyrite. In addition to the presence of $\mathrm{Cu}$, slightly oxidative conditions have been present during nucleation of pyrite, which has been indicated by crystallization of magnetite, but their possible role in twin formation remains unclear.

\section{Acknowledgements}

This work was supported by the Slovenian Research Agency under the National research project J1-6742 'Investigations of initial stages of phase transformations in minerals'. JZ acknowledges the financial support of the Slovenian Research Agency for young researchers under the Grant No. 1000-10-310072 and AČ thanks the support of Erasmus + mobility program. Part of this work was supported by the European Union $7^{\text {th }}$ Framework program under the Grant Agreement No. 312483ESTEEM2 (Integrated Infrastructure Initiative-I3).

\section{References}

Budkovič, T. (1981) Exploration at Žirovski vrh uranium deposit on principle of the geochemical cell. Geologija, 24/2, 7-23.

Cabral, A.R., Beaudoin, G. and Munnik, F. (2011) Lead in diagenetic pyrite: evidence for $\mathrm{Pb}$-tolerant bacteria in a red-bed $\mathrm{Cu}$ deposit, Quebec Appalachians, Canada. Mineralogical Magazine, 75, 295-302.

Canfield, D.E. and Berner, R.A. (1987) Dissolution and pyritization of magnetite in anoxic marine sediments. Geochimica et Cosmochimica Acta, 51, 645-659.

Cheney, E.S. and Jensen, M.L. (1966) Stable isotopic geology of the Gas Hills, Wyoming, uranium district. Economic Geology and the Bulletin of the Society of Economic Geologists, 61, 44-71.

Cliff, G. and Lorimer, G.W. (1975) The quantitative analysis of thin specimens. Journal of Microscopy, 103(2), 203-207.

Cocco, G. and Garavelli, C. (1954) Studio di alcuni problemi geochimici relativi al giacimento di ferro di Capo Calamita (Elba). Rendiconti della Società Mineralogica Italiana, 10, 269-350.

Coplen, T.B. and Krouse, H.R. (1998) Sulfur isotope data consistency improved. Nature, 392, 32.

Curtis, C.D., Hughes, C.R, Whiteman, J.A. and Whittle, C.K. (1985) Compositional variation within some sedimentary chlorites and some comments on their origin. Mineralogical Magazine, 49, 375-386.

Daneu, N., Rečnik, A., Yamazaki, T. and Dolenec, T. (2007) Structure and chemistry of (111) twin boundaries in $\mathrm{MgAl}_{2} \mathrm{O}_{4}$ spinel crystals from Mogok. Physics and Chemistry of Minerals, 34, 233-247.

Daneu, N. and Rečnik, A. (2012) The atomic-scale aspects of twinning and polytypism in minerals. Acta mineralogica-petrographica (Szeged), 7, 32-37.

Dolenec, T. (1983) The formation of uranium ore deposit Žirovski vrh. Doctoral dissertation. University of Ljubljana, 287 pp.

Donnay, G., Donnay, J.D.H. and Iijima, S. (1977) A highresolution electron micrograph of the twin boundary in pyrite. Acta Crystallographica, A33, 622-626.

Drake, H, Åström, M.E., Tullborg E.L., Whitehouse, M. and Fallick, A.E. (2013) Variability of sulfur isotope ratios in pyrite and dissolved sulfate in granitoid fractures down to $1 \mathrm{~km}$ depth - Evidence for widespread activity of sulfur reducing bacteria. Geochimica et Cosmochimica Acta, 102, 143-161.

Drev, S., Rečnik, A. and Daneu, N. (2013) Twinning and epitaxial growth of taaffeite-type modulated structures in BeO-doped $\mathrm{MgAl}_{2} \mathrm{O}_{4}$. CrystEngComm, 15, 2640-2647.

Folk, R.L. (2005) Nano-bacteria and the formation of framboidal pyrite: textural evidence. Journal of Earth System Science, 114, 369-374.

Goldschmidt, V. and Nicol, W. (1904) Spinellgesetz beim Pyrit und über Rangordnung der Zwillingsgesetze. Neues Jahrbuch für Mineralogie, 2, 93-113.

Gliszczynski von, S. (1950) Zur strukturgeometrischen Deutung der Zwillinge des Eisernen Kreutzes bei Pyrit. Neues Jahrbuch für Mineralogie - Monatshefte, 1, 25-29. 
Hessel (1869) Über einige Eisenkies-Zwillinge. Annalen der Physik, 213, 536-548.

Houten van, F.B. (1973) Origin of red beds. A review 1961-1972. Annual Review of Earth and Planetary Science, 1, 39-61.

Jahn, S. (2001) Pyrit-Zwillinge aus dem Raum VlothoExter. Mineralien Welt, 12, 32-51.

Jochum, J., Friedrich, G., Leythaeuser, D. and Littke, R. (1995) Intraformational redistribution of selected trace elements in the Posidonia Shale (Hils Syncline, NW Germany) caused by the thermal influence of the Vlotho Massif. Ore Geology Reviews, 9, 353-362.

Mlakar, I. (2002a) Val Gardena formation in $\mathrm{Pb}-\mathrm{Zn}-\mathrm{Hg}$ deposit Knapovže (Slovenia). Geologija, 45, 25-33.

Mlakar, I. (2002b) Val Gardena formation near Polhov Gradec (Slovenia). Geologija, 45, 35-45.

Pabst, A. (1931) Pressure-shadows and the measurement of the orientation of minerals in rocks. American Mineralogist, 16, 55-70.

Pačevski, A., Libowitzky, E., Živković, P. and Cvetković, L. (2008) Copper-bearing pyrite from the Čoka Marin polymetallic deposit, Serbia: Mineral inclusions or true solid-solution? The Canadian Mineralogist, 46, 249-261.

Rečnik, A. (2007) Mineral localities of Slovenia. Jožef Stefan Institute, Ljubljana, 355-367.

Rečnik, A., Daneu, N., Walther, T. and Mader, W. (2001) Structure and chemistry of basal-plane inversion boundaries in antimony oxide-doped zinc oxide. Journal of the American Ceramic Society, 84, $2657-2668$.

Seal, R.R., II (2006) Sulfur isotope geochemistry of sulfide minerals. Pp. 633-677 in Sulphide Mineralogy and Geochemistry (D.J. Vaughan, editor). Reviews in
Mineralogy \& Geochemistry, 61. Mineralogical Society of America and the Geochemical Society, Washington DC.

Skaberne, D. (1981) Sedimentological investigations of Val Gardena formation near Sovodenj. Masters thesis. University of Ljubljana, $218 \mathrm{pp}$.

Šrot, V., A. Rečnik, C. Scheu, S. Šturm and B. Mirtič (2003) Stacking faults and twin boundaries in sphalerite crystals from the Trepča mines in Kosovo. American Mineralogist, 88, 1809-1816.

Strunz, H and Tennyson, Ch. (1965) Strukturelle Deutung der Pyrit- und Markasitzwillinge. Neues Jahrbuch für Mineralogie - Monatshefte, 15, 247-248.

Tanelli, G., Benvenuti, M., Costagliola, P., Dini, A., Lattanzi, P., Maineri, C., Mascaro, I. and Ruggieri, G. (2001) The iron mineral deposits of Elba island: state of the art. Ofioliti, 26(2a), 239-248.

Thode, H.G., Monster, J., Dunford, H.B. (1961) Sulfur isotope geochemistry. Geochimica et Cosmochimica Acta, 25, 150-174.

Walker, T.R, Larson, E.E., Hoblitt, R.P. (1980) Nature and Origin of Hematite in the Moenkopi Formation (Triassic), Colourado Plateau: A Contribution to the Origin of Magnetism in Red Beds. Journal of Geophysical Research, 86(B1), 317-333.

Walther, T., Daneu, N. and Rečnik, A. (2004) A new method to measure small amounts of solute atoms on planar defects and application to inversion domain boundaries in doped zinc oxide. Interface Science, 12, 267-275.

Zavašnik, J. (2009) Pyrite occurrence at Katarina Mountain near Ljubljana. Diploma thesis. Faculty for Natural Sciences and Technology, University of Ljubljana, $104 \mathrm{pp}$. 